\title{
Folklore-based Historical Construction of Toyomarto Village
}

\author{
Maulfi Syaiful Rizal ${ }^{1}$, Nur Iksan ${ }^{2}$, I Kadek Yudi Astawan ${ }^{3}$ \\ \{maulfi_rizal@ub.ac.id ${ }^{1}$, iksan@ub.ac.id², yudiastawan@ub.ac.id ${ }^{3}$ \} \\ Universitas Brawijaya, Indonesia ${ }^{1,2,3}$
}

\begin{abstract}
Nowadays these oral literatures are written in a lot of writings, those writings can be about theories or knowledge. The role of literature is important in observing the origin of a village and writing it in the form of written literature. It is to understand the historical construction of Toyomarto village entirely and understanding the function of folklore for the villagers of Toyomarto, and according to Alan Dundes and literary semiotics theories in the stories that are growing in Toyomarto village. The data collecting procedure uses structured and non-structured interview technique, and observation, then transcription and translation. Data analysis technique includes interview results' analysis, observation, data marking or codification, data presentation, interpretation based on the function of oral literature and literary semiotics theories, and conclusion. The result of this study is the stories that are growing in Toyomarto is a historical construction that builds the names of Toyomarto areas. The function of oral literature also shows that the existence of Toyomarto is inseparable from every hamlet name in Toyomarto village. Semiotics or signifier of villages' origins is also seen in stories that were told by interviewees.
\end{abstract}

Keywords: Folklore, Oral literature, Semiotics, Toyomarto

\section{Introduction}

This research focuses on the folklore-based construction of the history of Toyomarto village, Singosari sub-district, Malang district, East Java, Indonesia. This village has an area of $\pm 905 \mathrm{Ha}$, is geographically on a plateau $\left(112^{\circ} 39^{\prime} 35.42^{\prime \prime} \mathrm{E}\right)$ and is bordering with Singosari subdistrict on the west side (7 $51^{\prime} 37.19^{\prime \prime}$ S). Long time ago, Toyomarto village was built on three hamlets, which are Bodean with Mbah Umar as the chief at the time, then Ngujung with Ki Buyut Poniten, followed by Ki Buyut Manab, and the last one was Sumberawan led by Ki Buyut Saleko. In the Dutch colonialism era, Ki Buyut Saleko was replaced by Mbah Tosari, and he united the three hamlets into one village named Toyomarto. Currently, Toyomarto village has its area expanded, splitting into seven hamlets which are surrounded by springs from every hamlet. The seven hamlets are, Sumberawan, Ngujung, Pentungwulung, Bodean Krajan, Bodean Putuk, Glathik, and Wonosari.

Toyomarto village has a long history. The background of the creation of Toyomarto happened in the Dutch colonialism era. Circulating story about the creation of Toyomarto village is about a group from Pati, Central Java, Indonesia. One of them was Mrs. Sadirah who exiled to Malang because of the Dutch invaders and she opened up a land to live. The land opening was eventually known by the Dutch, so Mrs. Sadirah decided to squat, and at that moment Mrs. Sadirah was called Mbah Kodok (Frog Granny). Gradually, the people living on the land increased and they decided to open up the surrounding land with Mbah Kodok as the 
leader. As the time went by, with the developments of every hamlet built, each hamlet got their own chiefs who were in the lineage of the previous chiefs. This makes the story of the creation of the village never disappeared or forgotten because it is passed down from generation to generation.

The leadership of Toyomarto village chief was started by Mr. Saleko who led Ngujung and Sumberawan hamlet only. After Mr. Saleko passed away, the position was officially given to Mr. Kosari, who took office in the Dutch colonialism era, then to Mr. Dullah in 1970 and he was replaced by Mr. Hamzah on 1987 who became the village chief for 25 years. When Mr. Hamzah stepped down, he was replaced by his son, Ir. M. Irjik on 1997. After his term of office was finished, Toyomarto village was led by Drs. Suryatiningsih, who won the election, from 2007 to 2019. The following election was won by Mr. Moh. Nari who took office for two terms, and currently, Mr. Sumito is the chief of Toyomarto village.

Toyomarto village is located on the foot of Arjuno Mountain with the elevation of \pm 622 meters above mean sea level, indirectly affecting the condition of natural resources in the village, so there are several springs, which are Kedung Biru, Watu Gede, and Sumberawan. The three has become patirtaan (sacred springs) since Singhasari Kingdom era. One of the most sacred springs according to the locals is the one around Sumberawan hamlet, which is located on Sumberawan temple. The opinion is strengthened by the experts, that Sumberawan temple was built around $14^{\text {th }}$ to $15^{\text {th }}$ century AD by Prabu Hayam Wuruk, the king of Majapahit, when he was staying in Singhasari on 1359, and it is researched by a Dutch archeologist named Van Romondt after it was found by the locals on 1904. Restoration was done on around 1928 and 1935 [1]. In the Negarakertagama book, written by Mpu Prapanca, on the $35^{\text {th }}$ pupuh (poem), $4^{\text {th }}$ line, "Karananin açru mankat $i$ huwusnira mpu masgeh bhawisyan (107a) laris, maluy $i$ kaçewakan/datn i sinhasari matutur manankil/mark, nrpati huwus mamuspa ri dalm/sudarmma

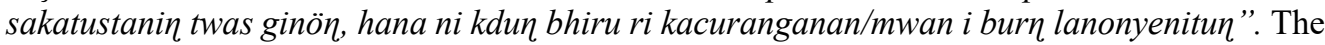
line means "due to the rushed departure, after being treated by the head of dormitory because he remembered his turn to be present in the Singashari town hall after his pilgrimage to the temple's tomb, the desire to be spoiled, savoring the essence of the scenery in Kedung Biru, Kasurangganan and Bureng”. Sumberawan temple is also called Kasurangganan which means garden of angels and heavenly garden of nymphs [1][2]. The land of Kasurangganan is the land of Kasogatan, a land given by the king to sogota, or Buddhist religious leader. The religions growing on the era of the biggest king of Singashari temple, who is King Kertanegara are Shiva Hinduism and Tantrayana Buddhism [3].

The temple and spring of Sumberawan have a connection. Stupa is the symbol of purity. The stupa of Sumberawan is the manifestation of Mandra or Mahameru (realm of gods) Mountain, while the lake is Amerta. The water is the water of life, the beverage of gods, which if drunk by humans, they will be spared from calamity and death. The absence of relics, statues ( arca), and relief on Sumberawan temple shows that the function of the temple is linked to the existence of the lake [1]. Tirta Amerta ritual is still preserved and held until now, the story of pentungan sari springs, and the myths and folklores growing in the area, where it is related to "petirtaan". The correlation between the springs and the historical construction of the village has not been able to be explored entirely for the identity and the history of this village with abundant springs. Aside from that, because there is no research about the village's history with folklore studies and there is no established accuracy about the history of Toyomarto village. Therefore, this research is done to understand the folklore-based construction of Toyomarto village history fully so that it could provide knowledge about the village's history and strengthen the village's identity to help develop Toyomarto village itself. 
This research is done by orientating on oral literature studies, Alan Dundes' concept and function of oral literature, and theory of literary semiotics for the growing folklores in Toyomarto village. The outline of research procedure consists of three steps, which are (1) prefield research with literature studies, surveying the field and making hypothesis related to the growing folklores in Toyomarto village, (2) exploration or data collecting in the field through observation, recording, interviews with informants, and voice recording. Collected data is then used to reveal the structural function of growing folklores, (3) data analysis. Data validity check, data processing and description is done in this step. The approaches used are descriptive qualitative, with all the data analyzed directly and arranged into drafts, so all the data collected matches the focus of the research. Based on the results, the folklores growing in Toyomarto are a historical construction that builds on the origin of the name Toyomarto. Semiotics or signifier of a village's origin is also seen in the stories told by interviewees.

\section{Research Method}

Oral literature is a literature work which is inherited orally through generation and it is a part of folklore or tradition. Oral folklore is a folklore that is purely oral [4]. The existence of oral literature and some cultures especially traditional society is considered very important because they only know literature in a form. One of the oral literature forms growing in Toyomarto village is folktale. Folktale is an oral literature because the source and the delivery are done orally for generations even though they are written into books nowadays.

The data source of this research is (1) oral and written texts of Toyomarto village's folktales, (3) informants, and (3) documents or observation results. Informant determination in this research is done with snowball sampling method which is determining the informant, then after the information from the previous informant and so on, that is done serially and sequentially.

The informants of this research is the actor or speakers of the folktales in Toyomarto village, which are witchdoctors, caretakers and the elders meeting the criteria as follows: (1) a native speaker living in Toyomarto village and is knowledgeable on folktales of Toyomarto; (2) is an adult, is at least 30 years old, so he/she is knowledgeable on the language and the culture; (3) is capable in understanding the intentions of the researchers; (4) is capable in storytelling and understand of the information needed by the researchers; (5) is neutral or does not have a personal interest; (6) has enough spare time for the interview. Aside from the primary informants, the researchers also collect other data from supporting informants who are village government officials and locals who have documentation of the stories relevant to this research.

The next technique is research data which are collected with non-structured interviews and observation. The interview technique is used to record some folktales in Toyomarto village which are not able to be recorded through observation [5]. The interviews are done in depth with a free format and tends to be a friendly ethnographic interview. The observation technique used in this research is non-participatory observation technique or regular observation [6].

After the interview data is collected, the next step is to transcript the data. Data transcription is writing down the interview audio into written text, usually by drawing every sound/font with a symbol [7]. Referring to transcription theory by Hutomo [8], the steps of transcription are as follows; (1) rough transcription; (2) perfected rough transcription; (3) adding punctuations, arranging text face; (4) digital finishing using a computer.

The finished transcription will enter the translation process, which is folktales writing in Javanese translated to Indonesian using a combination of translation technique words per words 
and is followed by literal translation. It is done to make information delivery and communication easier.

The last step is data analysis, by using two types of analysis which are content analysis and descriptive analysis, with descriptive qualitative approach. The usage of the analysis is intended to make the research more systematic and can be accounted for scientifically.

This step of research consists of three things, which are (1) pre-field, (2) exploration or data collecting step in the field with establishing information techniques by informants' sample establishment based on purposive sampling technique, and establishing informants with snowball sampling; a research data collecting technique with unstructured interviews and observation; transcription technique, where a writer converts verbal data to written data; translation technique; (3) data analyzation step by using content analysis and descriptive qualitative approach.

\section{Results and Findings}

\subsection{Toyomarto Village Construction Based on Folklore}

The first step of constructing the history of Toyomarto is by looking for data through interviews about lore's, mythologies, and legends in Toyomarto village, Singosari sub-district, Malang district, East Java - Indonesia. The formation of Toyomarto village is marked by springs in every hamlet. In accordance with the naming of Toyomarto, "toyo" and "marto". Toyo means water and marto means water of life (panguripan).

In revealing the history of Toyomarto village, the researchers also used semiotics theories. Semiotics is an analysis method to study signs [9]. The history of the naming of Toyomarto village's name as a whole is currently unknown. No one knows for sure how the name Toyomarto becomes the sign of the village. Words such as signifier and signified appear in semiotics theories or sciences about signs. Semiotics theories have three kinds of signs which are icon, index, and symbol. According to Pierce [10] sign is differentiated into three kinds of connection, which are (1) icon, if it is connected to similarities, (2) index, if it is an existential approach, and (3) symbol, if it is a relation which is conventionally built. Based on the object of research, the naming of Toyomarto village is a symbol sign. Symbol is a sign that does not have natural correlation with the signifier and is arbitrary, this corresponds with the naming of Toyomarto village which means "water of life". In Javanese, the naming of Toyomarto implies there are usages of local language symbols which are convened in the community and are agreed as a signifier (Toyomarto) and signified (a village which has abundant springs and supports the life of the community) have no natural correlation. The pronunciation of Toyo and Marto is an agreement of the community who uses Javanese as their communication tool.

Table 1. Literary semiotics' signified and signifier table

\begin{tabular}{clc}
\hline Sign & \multicolumn{1}{c}{ Signified } & \multicolumn{1}{c}{ Signifier } \\
\hline Symbol & $\begin{array}{l}\text { A village which has abundant springs and supports } \\
\text { the life's of the community. }\end{array}$ & Toyomarto village \\
\hline Symbol & $\begin{array}{l}\text { A hamlet where a spring was found in the swamps } \\
\text { in the afternoon when people were on their way to } \\
\text { work. }\end{array}$ & Sumberawan hamlet \\
\hline
\end{tabular}




\begin{tabular}{clc}
\hline Symbol & $\begin{array}{l}\text { A hamlet which was a territory ruled by Raka I } \\
\text { Hujung Mpu Madhura Lokaranjana. }\end{array}$ & Ngujung hamlet \\
\hline Symbol & $\begin{array}{l}\text { A hamlet which was a forest name pentung } \\
\text { formerly and the bamboo was named wulung. }\end{array}$ & Pentungwulung hamlet \\
\hline Symbol & $\begin{array}{l}\text { A hamlet which was a territory of Mbah Glatik, a } \\
\text { newcomer from Central Java who established a } \\
\text { land in Toyomarto's area. }\end{array}$ & Glatik hamlet \\
\hline Symbol & $\begin{array}{l}\text { A hamlet which has a meaning of wono (forest) and } \\
\text { sari (the core), implies a forest or a land to } \\
\text { cultivate. }\end{array}$ & Wonosari hamlet \\
\hline
\end{tabular}

Based on Table 1, The village names where the springs are located strengthened the proof of the locals' beliefs and the relationship with the name of the Toyomarto village. The existence of the biggest spring in the Toyomarto village is in Sumberawan hamlet, whether it is on the Sumberawan temple or on its surroundings. The symbols related to the existence of springs in Sumberawan hamlet with the origin of the hamlet which one of them is based on Mrs. Rosida's explanation, as the caretaker of the Sumberawan temple, can be seen below:

Sumberawan temple is the only Buddhist temple in East Java and why is it named Sumberawan? Because it is built on a water source (sumber) and the word rawan means lake or swamp, and the source below the temple is the biggest water source in the area and is used as an irrigation system surrounding the lake and the area (Rosida, 2020).

In literal term, the meaning of water source or lake is related to a spring in a place. It is strengthened with the words by Mr. Mukmin, as the chief of Sumberawan hamlet in the Toyomarto village, which is the existence of the word sumber meaning spring or water source, due to translation of Javanese society of sumber is a place where water pours out which is utilized by society for their lives.

The discovery of the swamp (rawa or rawan). Discovered the spring, the soil was moist, so the villagers discovered the spring. It was discovered at noon when the villagers were working together to find the spring, and it was called Sumberawan because it was found at noon (Mr. Mukmin, 2020).

In line with the general meaning of Toyomarto village, which is water of life, has a meaning that the water source in the village is used by the villagers in their lives. The meaning is still arbitrary, which means its meaning is based on the agreement of the villagers who speak the native language, in this case, the villagers of Toyomarto.

Oral history of the water source assured the villagers of Sumberawan's water. The level of language explained previously indicates that Sumberawan's water has a high status. It is related strongly as well with the meaning of Toyomarto which means water of life, which has the same meaning with tirta amerta. The context of the naming of a place is related with the unique characteristics as the identity of the place. Toponymy gives an overview about the historical contexts, events which are to be immortalized or remembered. Toponymic searching helps explore the historical contexts or the original state of the place when it was formed (Suliyati, 2012). Water is identical with "source of life" or "vitalizing". Toyomarto means water of life, water that gives life or vitalizing. Toyomarto is also heavily related to tirta amerta. Tirta amerta is the essence of life, the water which spares the one who consumes it from calamity, including death. The gods and angels who consume tirta amerta are immortal beings, they are never ill, beautiful, youthful, magical, and glorious. This is the benefit desired by them who conducts spiritual rituals in Sumberawan [3]. 
Other than data of symbols in the naming origin of Toyomarto village in Sumberawan hamlet, there are several data related with symbols and are related to the naming of hamlets in Toyomarto village. One of them is the naming of Petungwulung hamlet, as follows:

The history of Petungwulung is named Petung and Wulung. Petung means water and Wulung means forest. Long ago, there are a lot of bamboo trees in Petungwulung which still grows until now (Hartono, 2020).

Based on the interviews with Mr. Hartono, the chief of Petungwulung hamlet, the existence of water source in the hamlets of Toyomarto village becomes the basis for the naming of the village. It is shown on the data above, making the naming of Petungwulung relates to or can be used as a symbol to explain the meaning in the naming of Toyomarto village, because their meanings are similar. The similarities can be seen on the meaning of petung itself, which means water and wulung meaning bamboo forest. The meaning of water in petung does not only means water in a literal way, but it can also mean the existence of a spring around the bamboo forest on the hamlet, so it can be utilized by the locals.

The existence of the spring in every word in the name origins of every hamlet in Toyomarto can be a sign that the village's springs are abundant, so the local villagers which are represented by the former village government gave the name Toyomarto, hoping the springs in the village would give benefits for the villagers in every activity and even for every other life creature in the villages.

\subsection{The Function of Folklore for Toyomarto Villagers}

Looking at the folktales which itself a part of oral literature that is a part of folklore so folktales have a function for the supporting villagers [4]. Assuming that folktales have a function, in this research folklore function theory that is developed by Alan Dundes that is specified by Hutomo in oral literature is used. The existence of folktales in the society especially in Toyomarto village gives a meaning on its own for its supporting society. According to Dundes in Danandjaja [4] folklore has functions as follows; (1) aiding in education of the young; (2) promoting a group's feeling of solidarity, (3) providing socially sanctioned way is for individuals to censure other individuals; (4) serving as a vehicle for social protest; (5) offering and enjoyable escape from reality; (6) converting dull work into play.

In accordance with the theory of function by Dundes, there is a function of oral literary that grows in Toyomarto, which are:

1. Knowledge function, where folklore can be used as a tool to show the specialties of Toyomarto village to the public and as a guide for the public to know the history of the village from generation to generation. The existence of folktales in every hamlet in Toyomarto village is indirectly becomes an education tool for the society. This is due to every folktale grown has historical, social, and religious value that can be used as a guide for the surrounding society. The existence of mythologies and folktales grown indirectly become the base or the reason Tirta Amerta ritual or ceremony is held as a form of gratitude and honor from Toyomarto villagers to their ancestors;

2. Social solidarity function, villagers of Toyomarto who have the same knowledge about the village's history and the ancestors will respect one another. Forms of Toyomarto villager's solidarity is still embedded to this day. The ceremony of slametan or ceremony of gratitude to God which is held together is a form of harmony in solidarity. According to Ariani (2003), the slametan tradition is done by the Javanese to reach cosmic harmony. By doing slametan, they feel serene and at peace because slametan means doing the word from late ancestors who are still "alive" and live with them. Besides having a relationship with 
ancestors and god, slametan also strengthens horizontal-social relationships [11]. From here, we can see that slametan intended for spring sustainability is done by having verticaltranscendental and horizontal-social relationship. The balance of vertical and horizontal relationship is the effort to keep the balance of the cosmos. By doing slametan, the villagers hope for salvation.

3. Social critic function, an application of social regulations of the villagers in Toyomarto and traditions that is still preserved would result in rules that is still used until now. Social critic that comes from tradition will always be the walls for Toyomarto villagers who do the wrong things.

In modern thoughts, social regulations built among Toyomarto villagers is a tradition that is passed from generation to generation, which is still linked to myths and folklores, and is still perceived as fictional; so, it is often abandoned. But the villagers who still uphold their customs, tradition, use "feeling" more than ratio, where they presume a belief in a folklore truly happened and they are afraid to violate the words or the prohibitions.

The events linked to the violation of social regulations are told continuously as a warning. The tradition shaped from a myth or a folklore, and strengthened by the erection of sacred monuments proves to be effective in preventing damages of water source and the environment of Toyomarto village. In line with changes in thinking from religious-magical to scientific, rational, and technological, then the traditional effort of protecting springs sustainability begin to wane. The domination of capitalism has codified rituals and historical heritages so that it slowly erases the messages contained in various traditions of agrarian-traditional society [12]. The preservation of springs becomes technical efforts which often forget the cosmic balance, while traditional rituals are left to be cultural attraction in tourism commodity.

\section{Conclusion}

Based on the results of the research with informant establishing technique, data collecting technique, transcription technique, translation technique and data analysis technique obtained in the interviews with the heads of seven hamlets in Toyomarto village, it can be concluded that: (1) Folklore-based historical construction of Toyomarto village has a function that could enhance the function of the community's knowledge about the history of the village, stronger solidarity of the community due to the feeling of proud and brotherhood among the villager and the social critic in Toyomarto village as a control for traditional society preserved by the community; (2) The naming of Toyomarto is taken from Javanese which means water of life, in the semiotics theory the naming which has no correlation is called arbitrary. Toyomarto becomes a signifier of a village with abundant springs. (3) the function of folklores of Toyomarto village for its villagers are as a knowledge, social solidarity, and social critique.

\section{References}

[1] A. B. Wurianto, "Aspek budaya pada upaya konservasi air dalam situs kepurbakalaan dan mitologi masyarakat Malang," J. Humanit., vol. 4, no. 2, 2012.

[2] R. Soekmono, The Javanese candi: Function and meaning, vol. 17. Brill, 1995.

[3] A. Sudikno and S. Surjono, "Intangible Cultural Heritage Candi Sumberawan Dalam Perspekstif Kosmologi," in Prosiding Seminar Heritage IPLBI, 2017, p. 1.

[4] J. Danandjaja, Folklor Indonesia: ilmu gosip, dongeng, dan lain lain. Grafiti Pers, 1984.

[5] S. Y. Sudikan, Metode penelitian kebudayaan. Unesa Unipress, 2001. 
[6] P. Suparlan, "Metode penelitian kualitatif," Progr. Kaji. Wil. Amerika Progr. Pascasarj. Univ. Indones. Jakarta, 1994.

[7] H. Kridalaksana, "Kamus Linguistik." Gramedia, Jakarta, 1983.

[8] S. S. Hutomo, Mutiara yang terlupakan: Pengantar studi sastra lisan. Himpunan Sarjana Kesusastraan Indonesia, Komisariat Jawa Timur, 1991.

[9] H. Prasetyo and W. Sutopo, "Industri 4.0: Telaah Klasifikasi aspek dan arah perkembangan riset," J@ ti Undip J. Tek. Ind., vol. 13, no. 1, pp. 17-26, 2018.

[10] B. Nurgiyantoro, "Sastra Anak (Children's Literature)." Yogyakarta: Gadjah Mada University Press, 2013.

[11] Purwadi, Folklor Jawa. Yogyakarta: Pura Pustaka, 2012.

[12] I. Setiawan, "Ritual dalam Dekapan Pariwisata: Wacana dan Praktik Hegemoni Pasca Reformasi. Matatimoer Institute for Cultural Studies and Community Development," Metatimoer, 2017. [Online]. Available: http://metatimoer.or.id/2017/07/31/ritual-dalam-dekapan-pariwisatawacana-dan-praktik-hegemonik-pasca-reformasi. 